Check for updates

Cite this: Phys. Chem. Chem. Phys., 2021, 23, 1566

Received 31st July 2020 Accepted 16th December 2020

DOI: $10.1039 / \mathrm{d} 0 \mathrm{cp} 04067 \mathrm{c}$

rsc.li/pccp

\section{The importance of the bacterial cell wall in uranium(vi) biosorption $\dagger$}

\author{
Joseph Hufton, (D) *a John Harding, (D) ${ }^{b}$ Thomas Smith (D) ${ }^{c}$ and \\ Maria E. Romero-González (iD *ad
}

\begin{abstract}
The bacterial cell envelope, in particular the cell wall, is considered the main controlling factor in the biosorption of aqueous uranium(vi) by microorganisms. However, the specific roles of the cell wall, associated biomolecules, and other components of the cell envelope are not well defined. Here we report findings on the biosorption of uranium by isolated cell envelope components and associated biomolecules, with P. putida 33015 and B. subtilis 168 investigated as representative strains for the differences in Gram-negative and Gram-positive cell envelope architecture, respectively. The cell wall and cell surface membrane were isolated from intact cells and characterised by X-ray Photoelectron Spectroscopy (XPS) and Attenuated Total Reflectance-Fourier Transform Infrared (ATR-FT-IR) spectroscopy; revealing variations in the abundance of functional moieties and biomolecules associated with components of the cell envelope. Uranium biosorption was investigated as a function of cell envelope component and $\mathrm{pH}$, comparing with intact cells. The isolated cell wall from both strains exhibited the greatest uranium biosorption capacity. Deprotonation of favourable functional groups on the biomass as the $\mathrm{pH}$ increased from 3 to 5.5 increased their uranium biosorption capacity by approximately 3 fold. The results from ATR-FT-IR indicated that uranium(vI) biosorption was mediated by phosphate and carboxyl groups associated with proteins and phosphorylated biopolymers of the cell envelope. This includes outer membrane phospholipids and LPS of Gram-negative bacteria and teichoic acids, surface proteins and peptidoglycan from Gram-positive bacteria. As a result, the biosorption process of uranium(vi) to microorganisms is controlled by surface interactions, resulting in higher accumulation of uranium in the cell envelope. This demonstrates the importance of bacterial cell wall as the key mediator of uranium biosorption with microorganisms.
\end{abstract}

\section{Introduction}

Increased anthropogenic activity and the use of uranium in the nuclear fuel industry have caused large quantities of dissolved uranium to be released into the environment. ${ }^{1,2}$ Biosorption $^{3-5}$ and biomineralisation ${ }^{6-8}$ provide opportunities for the use of environmentally friendly processes that utilise the power of microorganisms to immobilise and remove uranium from

\footnotetext{
${ }^{a}$ Department of Geography, The University of Sheffield, Sheffield, S10 2TN, UK. E-mail: j.m.hufton@sheffield.ac.uk

${ }^{b}$ Department of Materials Science and Engineering, Sir Robert Hadfield Building, University of Sheffield, Mappin Street, Sheffield, S1 3JD, UK

${ }^{c}$ Biomolecular Sciences Centre, Sheffield Hallam University, City Campus, Sheffield S1 1WB, UK

${ }^{d}$ School of Engineering and Materials Science (SEMS), Queen Mary University of London, Mile End Road, London E1 4NS, UK.

E-mail:m.romero-gonzalez@qmul.ac.uk

$\dagger$ Electronic supplementary information (ESI) available: Characterisation of XPS spectra, uranium speciation, additional adsorption isotherms, Langmuir fittings, detailed FT-IR characterisation of cell envelope components and raw data. See DOI: $10.1039 /$ d0cp $04067 \mathrm{c}$
}

waste solutions. The realisation of these processes on large scales requires careful control of $\mathrm{pH}$, redox conditions and concentrations of uranium in the effluent, since these all affect its mobility in solution and, in turn, govern the radioactive material's interactions with microorganisms. ${ }^{2,9-11}$ Despite the amount of existing literature in this area, the biosorption and accumulation processes exhibited by microorganisms are still not fully understood at a mechanistic level, making it difficult to consider their use and application in remediation, extraction and reuse of radioactive materials.

It is known that the physiochemical interactions of bacterial cells with uranium are governed by intermolecular forces between functional groups associated with those of the interacting surface, in particular those associated with the cell wall. ${ }^{12-15}$ This has been suggested in numerous spectroscopic and microscopy techniques. Many studies and strains, including Gram-positive Bacillus species, ${ }^{16-21}$ Paenibacillus sp. JG-TB8, ${ }^{22}$ Gram-negative strains Pseudomonas fluorescens, ${ }^{23}$ Cupriavidus metallidurans ${ }^{24}$ and yeasts such as Saccharomyces cerevisiae ${ }^{25}$ have highlighted the cell wall's importance in uranium biosorption at 
the cell surface, as either the sole mechanism of uranium bioremediation or a precursor step to cell surface and intracellular biomineralisation.

However, the experimental approaches used in these studies make it difficult to see whether this process happens only at the outermost cell wall or can involve other components of the cell envelope. Uranium deposition onto the cell surface of Gram-negative strains Sphingomonas sp. S15-S1, ${ }^{26}$ Rhodopseudomonas palustris $^{24}$ and Acidovorax facilis $^{27}$ indicate that uranium interacts with the cell surface membrane as well as with the outer membrane of the Gram-negative cell wall. Similarly, uranium deposits were apparent at both cell wall and cell surface membrane of the yeast Rhodotorula mucilaginosa B11-R8. ${ }^{28}$

Despite the evidence for uranium sequestration at the cell surface, the contribution of each component of the cell envelope and associated biomolecules to the biosorption of uranium(vI) is largely unknown. The availability of functional groups associated with the cell envelope varies with microbial strain, depending in particular on whether their cell wall architecture is of Gram-positive or Gram-negative origin. ${ }^{5,29}$ Therefore, understanding the role of individual cell envelope components extends the ability to determine the localisation, interaction strength and immobilisation of uranium with microorganisms.

Many studies have investigated how intact cells sequester $\mathrm{U}(\mathrm{vI})$ from acidic environments, focusing solely on intact cells and purified polymers commercially available. ${ }^{30-33}$ To date, no studies have been performed on components extracted from the cell envelope.

This work aims to reveal the role of the different components of the bacterial cell envelope, in particular the cell wall, of Pseudomonas putida 33015 and Bacillus subtilis 168 in uranium biosorption from acidic environments. This was achieved by isolating and characterising components of the bacterial cell envelope and quantifying their capacity for uranium biosorption in comparison with intact cells. We hypothesised that the cell wall components would retain a greater amount of uranium from acidic environments due to an increase in abundance of cell surface functional moieties sensitive to the presence of uranium in comparison with those present in intact cells.

A range of spectroscopic techniques were used to study the biosorption process. X-ray photoelectron spectroscopy (XPS) is an experimental technique that provides elemental analysis of surfaces, and was used to characterise the components of the bacterial cell envelope following extraction and purification. It is therefore ideal for the characterisation of functional groups and the quantification of biomolecules within the cell wall, such as peptides, polysaccharides and lipid-like material. ${ }^{12,34-37}$ Attenuated Total Reflectance Fourier Transform-Infrared Spectroscopy (ATR-FT-IR) was used to identify the relative abundance of biomolecules and associated functional groups in components of the cell envelope. This spectroscopic technique was used to identify those biomolecules involved in uranium biosorption. ${ }^{38-42}$

The results from this study will give insight into how the difference in molecular composition and functional groups associated with specific components of the cell envelope and biomolecules affect the mechanistic processes involved in uranium biosorption. Furthermore, understanding these mechanistic processes is essential for designing an effective remediation process using bacterial biomass.

\section{Experimental procedures}

\subsection{Bacteria and growth conditions}

Two bacteria were used in this study; Pseudomonas putida 33015 (ATCC 33015) and Bacillus subtilis 168 (ATCC 23857) were obtained from LGC standards. $P$. putida 33015 was grown in sodium benzoate media $\left(3.0 \mathrm{~g} \mathrm{~L}^{-1}\left(\mathrm{NH}_{4}\right)_{2} \mathrm{HPO}_{4}, 1.2 \mathrm{~g} / \mathrm{LKH}_{2} \mathrm{PO}_{4}, 5.0 \mathrm{~g} \mathrm{~L}^{-1}\right.$ $\mathrm{NaCl}, 0.2 \mathrm{~g} \mathrm{~L}^{-1} \mathrm{MgSO}_{4} \cdot \mathrm{H}_{2} \mathrm{O}, 0.5 \mathrm{~g} \mathrm{~L}^{-1}$ yeast extract, $3.0 \mathrm{~g} \mathrm{~L}^{-1}$ sodium benzoate) and B. subtilis 168 in nutrient broth (Sigma: 70122) in $1 \mathrm{~L}$ cultures until cells reached late exponential phase in their growth cycle, while shaking at $170 \mathrm{rpm}\left(30^{\circ} \mathrm{C}\right)$.

\subsection{Cell fractionation}

A cell fractionation method using a French pressure cell and ultracentrifuge was adapted and used $^{43}$ to isolate cell wall and membrane components for spectroscopic characterisation and subsequent uranium biosorption experiments. This method of fractionation is widely reported for isolating pure cell wall and membrane components from multiple bacterial strains, without the need for assessing purity, ${ }^{44-46}$ and has been successfully adapted using different disruptive apparatus. ${ }^{4-49}$ A schematic of the isolation cell envelope components is shown in Fig. 1. Two main products are obtained through this process: cell wall components and cell membrane components. For Gramnegative bacteria, the cell wall components include peptidoglycan, capsular polysaccharides, lipopolysaccharides and porins. For Gram-positive bacteria, the cell wall components are mainly peptidoglycan, surface proteins, cell wall associated proteins, teichoic and lipoteichoic acids. The cell membrane components are common for both Gram-positive and Gram-negative bacteria and their composition is characterised by the presence of phospholipids, membrane associated proteins and membranederived oligosaccharides (MDO).

The cells from a 1 L culture of $P$. putida 33015 and B. subtilis 168 were harvested by centrifugation at $5000 \mathrm{~g}$ (10 $\mathrm{min})$, washed 3 times in $0.1 \mathrm{M} \mathrm{NaCl}$ and re-suspended in $10 \mathrm{~mL}$ ice-cold 18.2 $\mathrm{M} \Omega$ ultrapure water. $\mathrm{H}_{2} \mathrm{O}$ was used, rather than a buffered solution, as previously prepared, ${ }^{43}$ to prevent contamination from excess buffer constituents and to ensure the purity of extracted cell envelope components for uranium biosorption experiments. The concentrated cell suspension was passed through a French pressure cell (20000 PSI, $\left.4{ }^{\circ} \mathrm{C}\right)$ three times to break open the cells to isolate cell wall and membrane components. The lysed cells were centrifuged $\left(3000 g, 4{ }^{\circ} \mathrm{C}\right.$, $2.5 \mathrm{~min}$, twice) to remove any intact cells and any other debris from the cell disruption.

To isolate cell wall components, the cell lysate was centrifuged $\left(27000 \mathrm{~g}, 4^{\circ} \mathrm{C}, 30 \mathrm{~min}\right)$, washed $18.2 \mathrm{M} \Omega$ ultrapure water multiple times, to ensure purity, and the pellet stored at $-20{ }^{\circ} \mathrm{C}$. The remaining supernatant was subject to the same centrifugation parameters and pellets pooled to give cell wall components. 


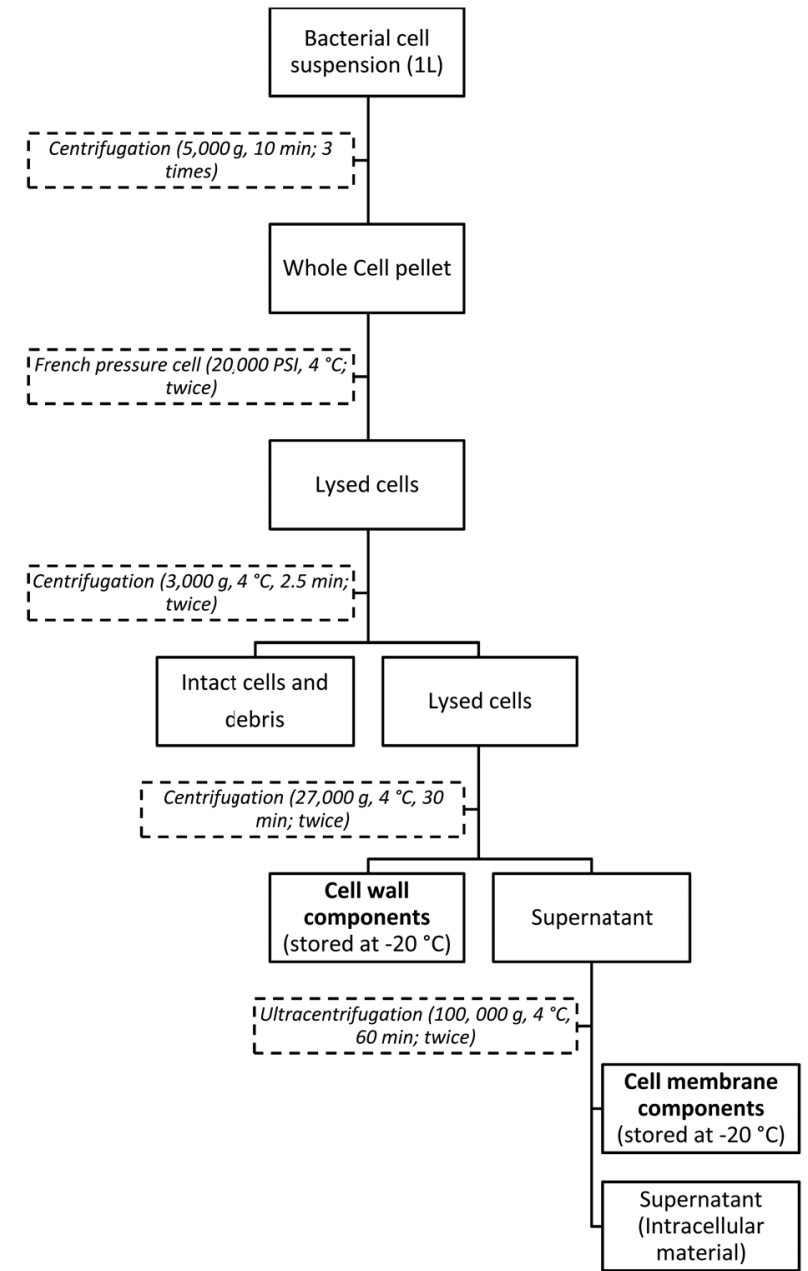

Fig. 1 Schematic for the isolation of cell wall and membrane components from bacterial cells.

To isolate cell membrane components, the remaining supernatant was subject to ultracentrifugation $\left(100000 \mathrm{~g}, 4{ }^{\circ} \mathrm{C}\right.$, $\left.60 \mathrm{~min}\right)$. The pellet was washed as before and stored at $-20{ }^{\circ} \mathrm{C}$. The remaining supernatant was spun again with the pellet washed and pooled to give cell membrane components. The final supernatant was subsequently characterised as cell cytoplasm and associated intracellular components.

The isolated cell wall, membrane components and cytoplasm were lyophilized (Alpha 1-2 LD Plus freeze dryer) to determine dry weights and to investigate their uranium biosorption capabilities.

No chemical or enzymatic lysis techniques were applied to break open the cells. This was to ensure that all the uranium was interacting with the biomass and not with any chemicals or enzymes from the fractionation process.

\subsection{Molecular characterisation of cell envelope components using XPS}

The percentage abundance of peptide, polysaccharide and hydrocarbon-like material (i.e., lipids) in the isolated components of the cell envelope was characterised by XPS. XPS analysis was conducted using a KRATOS AXIS 165 Ultra Photoelectron spectrometer with an $\mathrm{Al} \mathrm{K} \alpha$ X-ray source (1486.6 eV). Each sample was mounted on indium foil and analysed by a wide survey scan (pass energy $160 \mathrm{eV}, 1.0 \mathrm{eV}$ step size) and a high-resolution scan (pass energy $20 \mathrm{eV}, 0.1 \mathrm{eV}$ step size) for carbon, oxygen, nitrogen and phosphorus. Binding energies were determined using the C 1s component set at $285.0 \mathrm{eV}$, attributed to carbon bound only to carbon and hydrogen, using the CasaXPS software (Version 2.3.16). The full width half maximum was kept constant for subsequent peak calibration.

\subsection{Uranium biosorption}

To determine the uranium biosorption capacity of each cell component, $1 \mathrm{mg} \mathrm{mL}{ }^{-1}$ of biomass was incubated with increasing concentrations of uranium $(0.125 \mathrm{mM}$ to $4 \mathrm{mM})$ at $\mathrm{pH} 3,4.25$ and 5.5, and at $25{ }^{\circ} \mathrm{C}$. U(vi) solutions were prepared using $0.1 \mathrm{M}$ uranyl nitrate hexahydrate $\left(\mathrm{UO}_{2}\left(\mathrm{NO}_{3}\right)_{2} \cdot 6 \mathrm{H}_{2} \mathrm{O}\right)$ in $1 \% \mathrm{HNO}_{3}$ (Fluka Analytical: 94270). The $\mathrm{pH}$ was adjusted by the addition of $\mathrm{HCl}$ or $\mathrm{NaOH}$ while the ionic strength was controlled by the addition of $0.1 \mathrm{M}$ $\mathrm{NaCl}$. Following uranium biosorption, the biomass was removed from solution $\left(10000 \mathrm{~g}, 4{ }^{\circ} \mathrm{C}, 10 \mathrm{~min}\right)$ and the remaining uranium left within the supernatant was acidified using $1 \% \mathrm{HNO}_{3}$ and analysed using a Spectro-Ciros-Vision ICP - OES. Instrument parameters were set at 1400 watts with a coolant flow of $12.00 \mathrm{~L} \mathrm{~min}{ }^{-1}$, auxiliary flow at $1.00 \mathrm{~L} \mathrm{~min}{ }^{-1}$, nebuliser flow at $0.85 \mathrm{~L} \mathrm{~min}^{-1}$ and a pump speed during analysis set at

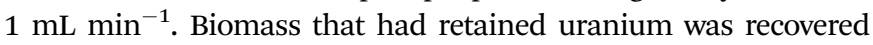
by centrifugation $\left(10000 \mathrm{~g}, 4{ }^{\circ} \mathrm{C}, 10 \mathrm{~min}\right)$, washed three times using $0.1 \mathrm{M} \mathrm{NaCl}$ and lyophilised (Alpha 1-2 LD Plus freeze dryer).

\subsection{ATR-FT-IR}

Measurements were performed using Attenuated Total Reflectance (ATR) - FT-IR to identify the functional groups of each cell surface component which interact with uranium. These were obtained using a Silver Gate Evolution ATR accessory, consisting of a germanium crystal, coupled to a PerkinElmer Spectrum One FT-IR spectrometer. A total of 30 scans were performed on each sample within the scanning range of $4000-800 \mathrm{~cm}^{-1}$. An average spectrum was obtained from 3 replicates, baseline corrected and normalised to 1.5 absorbance (arbitrary units) using the $\sim 1650 \mathrm{~cm}^{-1}$ amide I peak within the control sample (containing no uranium). Data acquisition and processing were performed using PerkinElmer Spectrum version 3.3 to obtain peak positions and relative peak intensities.

\section{Results and discussion}

\subsection{Characterisation of components of the cell envelope using XPS}

In order to identify the role of the bacterial cell envelope in uranium biosorption, the key components of the cell envelope were first isolated, purified, and characterised by XPS. XPS was used to identify the surface functional groups characteristic of the intact bacteria and their cell envelope components since the probing X-rays penetrate only the top 2 to $5 \mathrm{~nm}$ of the sample, eliminating interference from intracellular components. ${ }^{36}$ XPS survey spectra and high-resolution $\mathrm{C} 1 \mathrm{~s}, \mathrm{O} 1 \mathrm{~s}, \mathrm{~N} 1 \mathrm{~s}$ and $\mathrm{P} 2 \mathrm{p}$ 
Table 1 The chemical composition of model compounds used for the calculation of cell surface constituent abundance

\begin{tabular}{|c|c|c|c|c|}
\hline \multirow{2}{*}{$\begin{array}{l}\text { Cell surface } \\
\text { constituent }\end{array}$} & \multirow{2}{*}{$\begin{array}{l}\text { Model carbon } \\
\text { compound }\end{array}$} & \multicolumn{2}{|c|}{$\begin{array}{l}\text { [Atomic] ratio } \\
\text { (atom/atom) }\end{array}$} & \multirow{2}{*}{$\begin{array}{l}{[\text { Carbon] }} \\
\left(\mathrm{mmol} \mathrm{g}^{-1}\right)\end{array}$} \\
\hline & & $\mathrm{O} / \mathrm{C}$ & $\mathrm{N} / \mathrm{C}$ & \\
\hline Polysaccharides & Glucan $\left(\mathrm{C}_{6} \mathrm{H}_{10} \mathrm{O}_{5}\right)$ & 0.833 & 0.000 & 37.0 \\
\hline Peptides & $\begin{array}{l}\text { P. fluorescens OE } \\
28.3 \mathrm{OMP}^{a}\end{array}$ & 0.325 & 0.279 & 43.5 \\
\hline Lipid & Hydrocarbon $\left(\mathrm{CH}_{2}\right)_{n}$ & 0.000 & 0.000 & 71.4 \\
\hline
\end{tabular}

${ }^{a}$ Outer membrane protein (OMP) amino acid analysis for peptide atomic concentration ratios and relative protein abundance.

spectra of intact $P$. putida 33015 and B. subtilis 168 cells and cell envelope components are shown in Fig. S1 and S2 (ESI $\dagger$ ). A detailed interpretation of high-resolution XPS spectra is given in Supplementary Information 1 (ESI $\dagger$ ).

Secondly, XPS was used to quantify the percentage elemental abundance of $\mathrm{C}, \mathrm{O}, \mathrm{N}$ and $\mathrm{P}$ within the outermost layer of each sample. Four biological replicates of each cell envelope component were used to calculate an average and standard deviation. From this, the abundances of polysaccharides, peptides and hydrocarbon-like compounds were determined. ${ }^{12,34,36}$ This approach compared the measured concentration ratios $\mathrm{O} / \mathrm{C}$ and $\mathrm{N} / \mathrm{C}$, at the carbon concentration in the isolated components of the cell envelope, with the atomic concentration ratios $\mathrm{O} / \mathrm{C}$ and N/C for model compounds representative of the three classes of cell envelope constituents, Table 1.

Eqn (1)-(3) and the carbon concentration of each model carbon compound (Table 1) were used to determine the percentage of polysaccharides, peptides and hydrocarbon-like compounds in the cell envelope, where $\mathrm{C}_{\mathrm{PEP}}, \mathrm{C}_{\mathrm{PS}}$, and $\mathrm{C}_{\mathrm{LIP}}$ are the atomic carbon concentrations of the peptides, polysaccharides and lipids within the bacterial surface biomass. ${ }^{12}$

$$
\begin{gathered}
\mathrm{O} / \mathrm{C}=0.325\left(\mathrm{C}_{\mathrm{PEP}} /[\mathrm{C}]\right)+0.833\left(\mathrm{C}_{\mathrm{PS}} /[\mathrm{C}]\right) \\
\mathrm{N} / \mathrm{C}=0.279\left(\mathrm{C}_{\mathrm{PEP}} /[\mathrm{C}]\right) \\
1=\left(\mathrm{C}_{\mathrm{PEP}} /[\mathrm{C}]\right)+\left(\mathrm{C}_{\mathrm{PS}} /[\mathrm{C}]\right)+\left(\mathrm{C}_{\mathrm{LIP}} /[\mathrm{C}]\right)
\end{gathered}
$$

When intact cells were previously analysed by XPS, it was assumed that only the outermost $2-5 \mathrm{~nm}$ was analysed since this distance is the maximum penetration of X-rays from the instrument. $^{34-37,50}$ However, as the cell fractionation method used in this study is a well-defined method to isolate purified cell wall and membrane components, ${ }^{43}$ it is expected that the abundance of biomolecules detected by XPS will be representative of the entire component of the cell envelope. Therefore, the calculated results should confirm differences in composition of cell envelope architecture of the bacteria used in this study, Table 2 .

There was an almost equal abundance of peptide, polysaccharides and lipid compounds near the surface of intact P. putida cells. However, in the cell wall components there was an increase in the proportion of both peptides and a decrease in the proportion of polysaccharides compared with intact cells. A greater proportional decrease of polysaccharides in the cell membrane was attributed to a lack of polysaccharide-like compounds, such as peptidoglycan, present in small quantities in the Gram-negative cell wall. The increase in percentage abundance of peptides following cell fractionation was attributed to proteins present within the outer and cell surface membrane. No significant difference in hydrocarbon like material, associated with outer membrane phospholipids, were observed between intact cells and isolated cell wall components.

The surface of the intact $B$. subtilis cells was composed of almost equal amounts of peptides and polysaccharides while hydrocarbon-like compounds comprised $23.8 \pm 2.0 \%$. It has been suggested that the hydrocarbon-like material found in the surface of B. subtilis should be ascribed to lipoteichoic acids ${ }^{51}$ (rather than ruptures of the cell wall and X-ray penetration of cell surface membrane phospholipids) as it has been shown that freeze-drying intact bacteria does not rupture the cell walls. $^{52}$ The proportion of peptides and polysaccharides to lipid material increased within isolated cell wall components from B. subtilis following the fractionation of intact cells. Previous XPS studies had found the cell surface to be rich in phosphate groups as well as protonated nitrogen, associated with protonated amino acids and alanine or (lipo) teichoic acids. ${ }^{50}$ A decrease in

Table 2 Binding Energies (eV), assignments and quantification of XPS Spectral Bands of intact cell, cell wall and cell membrane isolates from P. putida 33015 and $B$. subtilis 168. Total carbon, nitrogen, oxygen and phosphorus were obtained from the low-resolution wide scans to calculate the

\begin{tabular}{|c|c|c|c|c|c|c|}
\hline \multirow[b]{3}{*}{ Component } & \\
\hline & \multicolumn{3}{|c|}{ P. putida 33015} & \multicolumn{3}{|l|}{ B. subtilis 168} \\
\hline & Intact cells & Cell wall & Cell membrane & Intact cells & Cell wall & Cell membrane \\
\hline Total C & $69.46 \pm 1.84$ & $71.37 \pm 1.07$ & $73.26 \pm 0.68$ & $65.96 \pm 0.74$ & $62.87 \pm 1.87$ & $73.61 \pm 0.95$ \\
\hline Total N & $5.44 \pm 0.38$ & $7.66 \pm 0.52$ & $8.27 \pm 0.24$ & $6.03 \pm 0.3$ & $6.63 \pm 0.56$ & $6.89 \pm 0.6$ \\
\hline Total O & $23.07 \pm 1.67$ & $19.49 \pm 0.59$ & $17.08 \pm 0.34$ & $25.46 \pm 0.54$ & $27.77 \pm 1.41$ & $18.31 \pm 0.48$ \\
\hline Total P & $2.02 \pm 0.04$ & $1.48 \pm 0.14$ & $1.37 \pm 0.12$ & $2.56 \pm 0.15$ & $2.74 \pm 0.11$ & $1.19 \pm 0.15$ \\
\hline $\mathrm{O} / \mathrm{C}^{a}$ & $33.2 \pm 3.2$ & $27.3 \pm 1.2$ & $23.3 \pm 0.7$ & $38.6 \pm 1.2$ & $0.442 \pm 3.35$ & $24.9 \pm 0.9$ \\
\hline $\mathrm{N} / \mathrm{C}^{a}$ & $7.8 \pm 0.7$ & $10.7 \pm 0.9$ & $11.3 \pm 0.4$ & $9.1 \pm 0.5$ & $10.5 \pm 1.2$ & $9.4 \pm 0.9$ \\
\hline $\mathrm{P} / \mathrm{C}^{a}$ & $2.9 \pm 0.1$ & $2.1 \pm 0.2$ & $1.9 \pm 0.2$ & $3.9 \pm 0.2$ & $4.4 \pm 0.2$ & $1.6 \pm 0.2$ \\
\hline Peptide & $33.97 \pm 2.35$ & $46.58 \pm 3.15$ & $49.79 \pm 1.5$ & $38.02 \pm 1.89$ & $42.08 \pm 3.59$ & $41.8 \pm 3.55$ \\
\hline Polysaccharides & $34.31 \pm 3.39$ & $21.11 \pm 0.52$ & $14.71 \pm 0.24$ & $38.15 \pm 1.03$ & $41.71 \pm 2.25$ & $20.48 \pm 1.5$ \\
\hline Hydrocarbons & $31.72 \pm 4.36$ & $32.31 \pm 3.01$ & $35.5 \pm 1.61$ & $23.83 \pm 1.97$ & $16.21 \pm 4.92$ & $37.72 \pm 2.64$ \\
\hline
\end{tabular}
macromolecular composition, from 4 biological replicates

Concentration $(\% \pm \mathrm{SD})$

${ }^{a}$ Atomic concentration ratios with respect to total carbon, multiplied by 100 . 
the relative abundance of lipids in the B. subtilis cell wall components was ascribed to a lack of lipoteichoic acid content due to that compound being covalently bound to the cell surface membrane.

Elevated phosphate concentrations were attributed to phosphorylated proteins and polysaccharides within the Gram-positive cell wall. The phosphate-related compounds create the surface negative charge at low $\mathrm{pH}$ with a point of zero charge at $\mathrm{pH} 2.2 .^{53,54}$ Furthermore, the molecular composition of the B. subtilis cell wall can change as a function of $\mathrm{pH}$ and also in the presence of adsorbed heavy metal species. An increase in lipoteichoic acid content and a decrease in polysaccharide and peptide content was observed in the cell surface of intact $B$. subtilis cells as the $\mathrm{pH}$ of the solution that the cells were suspended in was increased. ${ }^{51}$

Hydrocarbon-like compounds were attributed to the outer membrane of the $P$. putida cell wall and phospholipids and other lipid material in the cell surface membrane in both bacterial strains. The low abundance of polysaccharides in cell membrane isolates could be attributed to bound polysaccharides such as lipoteichoic acids (in the Gram-positive B. subtilis). ${ }^{12,34-37}$

The characteristics of the fractions as obtained using XPS correspond to the typical morphological distribution of macromolecules in each of the different cell compartments for both P. putida and B. subtilis. As expected, there was a higher proportion of polysaccharides in the cell wall fraction compared to the cell membrane, for example, suggesting that this type of components preferred to be located mainly in the cell wall. This finding suggests that despite the limitations of the extraction method used, it provides a good representation of the molecular composition of the cell components per fraction.

\subsection{Uranium biosorption}

The ability of intact cells and isolated components of the cell envelope to retain uranium through biosorption from solution was studied by mixing $1 \mathrm{mg} \mathrm{mL} \mathrm{m}^{-1}$ biomass with solutions of increasing uranium concentration (0.125-4 mM) at $\mathrm{pH} \mathrm{3,} 4.25$ and 5.5 for 48 hours at $30{ }^{\circ} \mathrm{C}$. The biosorption capacity $\left(q_{\mathrm{e}}\right)$ was calculated, eqn (4), in which $C_{\mathrm{e}}$ and $C$ are the uranium concentrations ( $\mathrm{mol} \mathrm{L}^{-1}$ ) in solution before and after biomass interaction, respectively. $V$ is the reaction volume $(\mathrm{mL})$ and $m$ is the biomass weight $(\mathrm{mg})$.

$$
q_{\mathrm{e}}=\left(\left(C_{\mathrm{e}}-C\right) \times V\right) / m
$$

Fig. 2 shows the biosorption isotherms for intact cells from both bacterial strains between $\mathrm{pH}$ 3-5.5 and for their cell wall and membrane isolates at $\mathrm{pH} 5.5$, calculated from 3 biological replicates. Measurements were also performed in triplicate when analysed by ICP-OES. Biosorption isotherms for cell wall and membrane isolates of both strains in the $\mathrm{pH}$ range studied are displayed in Fig. S3 (ESI $\dagger$ ).

For both strains and their respective cell envelope components studied, greater removal of uranium from solution was observed as the solution $\mathrm{pH}$ increased from 3 to 5.5. The isotherms obtained for all samples follow a typical curve where
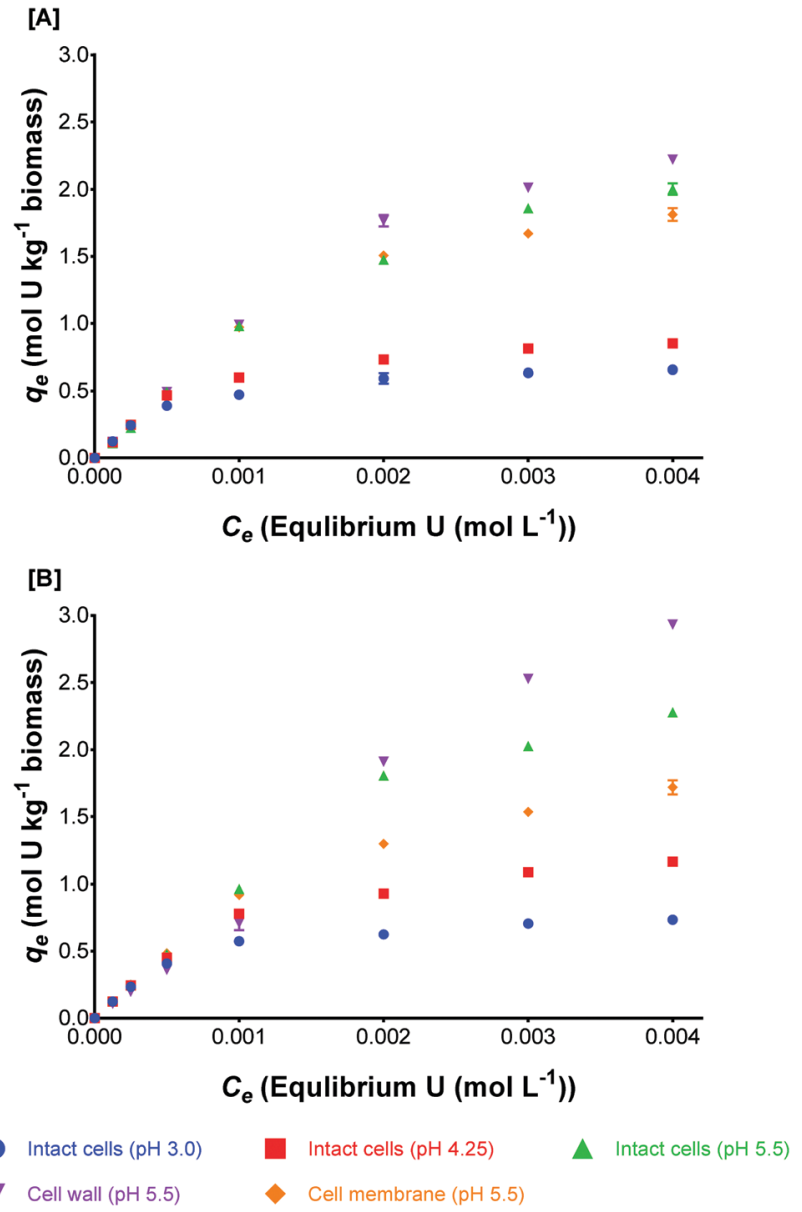

Fig. 2 Uranium biosorption isotherms for P. putida $33015[\mathrm{~A}]$ and $B$. subtilis 168 [B], respectively.

a plateau is observed towards higher concentrations of $\mathrm{U}(\mathrm{VI})$ in solution. For both strains in this study, there is a marked difference between the sorption capacity of intact cells at pH 3 and 4.25 compared to the process studied at $\mathrm{pH}$ 5.5.

The biosorption process is affected by $\mathrm{pH}$ since both the surface charge of the cell envelope components and the speciation of $\mathrm{U}(\mathrm{vI})$ are determined by the solution $\mathrm{pH}$. The estimated speciation of $\mathrm{U}(\mathrm{VI})$ in solution, in the presence of $0.1 \mathrm{M} \mathrm{NaCl}$, changed as a function of $\mathrm{pH}$ (Visual MINTEQ), Table S1 (ESI $\dagger$ ). At $\mathrm{pH} \mathrm{3,} \mathrm{the}$ dominant $\mathrm{U}(\mathrm{vI})$ species in solution was the highly mobile $\mathrm{UO}_{2}{ }^{2+}$ ion ( $\sim 93 \%$ ) within the concentration range studied. At $\mathrm{pH} 4.25$, $\mathrm{UO}_{2}{ }^{2+}$ was still the dominant species, however its abundance decreased as the uranium concentration in solution increased. Other species formed included $\mathrm{UO}_{2} \mathrm{OH}^{+}$and $\left(\mathrm{UO}_{2}\right)_{2}(\mathrm{OH})_{2}{ }^{2+}$, with the latter increasing as the uranium concentration increased. At $\mathrm{pH} 5.5$, the dominant uranium species were $\left(\mathrm{UO}_{2}\right)_{3}(\mathrm{OH})_{5}{ }^{+}$and $\left(\mathrm{UO}_{2}\right)_{4}(\mathrm{OH})_{7}^{+}$, with the former decreasing and latter increasing as the uranium concentration in solution increased.

For intact $B$. subtilis cells the amount of uranium biosorbed was 0.73, 1.17 and $2.28 \mathrm{~mol} \mathrm{U}(\mathrm{vI}) \mathrm{kg}^{-1}$ biomass from $4 \mathrm{mM} \mathrm{U}(\mathrm{vI})$ solution at $\mathrm{pH} \mathrm{3,4.25}$ and 5.5, respectively. This was substantially larger than that for intact $P$. putida cells which retained $0.66,0.85$ and $2.00 \mathrm{~mol} \mathrm{U}(\mathrm{vI}) \mathrm{kg}^{-1}$ biomass at $\mathrm{pH} 3,4.25$ and 5.5, respectively. 
The biosorption process is driven by interactions between aqueous $\mathrm{U}(\mathrm{vI})$ species and functional groups with a negative surface charge due to the influence of solution $\mathrm{pH}$. The point of zero charge (pzc), at which the bacterial cell surfaces of intact $P$. putida and B. subtilis cells exhibit a net neutral charge, was calculated previously at $\mathrm{pH} 2.8$ and 2.2 respectively. ${ }^{53-55}$ Therefore, the net negative charge of the bacterial cell surface of $B$. subtilis is greater than that of $P$. putida. This would result in a greater number of electrostatic interactions between deprotonated uranium-favourable functional groups and positively charged $\mathrm{U}(\mathrm{vI})$ species in the former case. Furthermore, a low pzc explains an increase in the biosorption capacity of both strains, approximately 3 fold, as the $\mathrm{pH}$ increased from 3 to 5.5 .

Differences in the composition of the bacterial cell envelope and differences in the number of functional groups could be attributed to differences in uranium retention as a function of species. Uranium biosorption has been described in terms of interactions with phosphate, hydroxyl, carboxyl and amino groups. ${ }^{9}$ The bacterial cell envelope of $B$. subtilis is composed predominantly of polysaccharides, lipoteichoic acids and peptides, contributing to the increased number of phosphate hydroxyl, carboxyl and amino groups. ${ }^{50}$ The cell envelope of $P$. putida contains large quantities of phospholipids and peptides, with the former increasing the number of esters and phosphates. Esters have not been shown to readily interact with uranium from solution in previous studies. Phosphates, however, readily interact with uranium. ${ }^{23,24,26}$

An increase in the biosorption capacity of cell wall isolates compared to intact cells highlighted the importance of the functional groups associated with the bacterial cell wall in uranium biosorption. Cell wall components from $B$. subtilis biosorbed a larger amount of U(vI), $2.93 \mathrm{~mol} \mathrm{U}(\mathrm{vI}) \mathrm{kg}^{-1}$ biomass, from $4 \mathrm{mM}$ solution, at $\mathrm{pH} 5.5$ than $P$. putida cell wall components, $2.22 \mathrm{~mol} \mathrm{U}(\mathrm{vI}) \mathrm{kg}^{-1}$ biomass.

Cell wall components from both bacterial strains exhibited a higher uranium retention capability than that of intact cells, possibly due to the increased number of uranium-favourable functional groups associated with the cell walls of both strains. Cell wall isolation increases the surface area exposure for interactions with $\mathrm{U}(\mathrm{vI})$ species in comparison with intact cells.

Cell membrane components from both bacterial strains exhibited a lower $\mathrm{U}(\mathrm{vI})$ biosorption capacity to that observed for intact cells and cell wall isolates. $B$. subtilis cell membrane components retained $1.72 \mathrm{~mol} \mathrm{U}(\mathrm{vI}) \mathrm{kg}^{-1}$ biomass following suspension in $4 \mathrm{mM}$ uranium solution at $\mathrm{pH}$ 5.5. By comparison, P. putida cell membrane components retained $1.81 \mathrm{~mol} \mathrm{U}(\mathrm{vI}) \mathrm{kg}^{-1}$ biomass. This decrease was attributed to the proportional increase in the number of uranium-unfavourable and non-reactive functional groups, such as those associated with the lipid bilayers. A decrease in the concentration of uranium-favourable groups from other cell surface biomolecules, such as polysaccharides, that were present within intact cell and cell wall components, would decrease the retention capacity of cell membrane components in comparison.

These results demonstrate that accounting for the removal of $\mathrm{U}(\mathrm{vI})$ from solution using intact cell dry weight underestimates the capacity of these organisms to sequester uranium using their cell wall. Intracellular components of intact cells contribute to their dry weight but may not contribute to the retention of uranium, and hence result in a lower uranium biosorption capacity per kg of biomass. Using the cell fractionation approach provides a better approximation of the retention capacity from intact cells, based on the direct contribution from key components of the cell envelope deemed responsible for uranium biosorption.

The Freundlich isotherm model was used to estimate the sorption parameters of the process studied here. This absorption model assumes a heterogeneous adsorbent surface with multiple adsorption sites and different binding affinities for the multiple $\mathrm{U}(\mathrm{vI})$ species. The bacterial cell surface can be considered as a multiple adsorption site system, rich in functional moieties that exhibit a deprotonation behaviour within the $\mathrm{pH}$ range studied. ${ }^{9}$

The Freundlich constants were calculated by a plot of triplicate data of the logarithms of $C_{\mathrm{e}} v s . q_{\mathrm{e}}$. The corresponding linear regression can be applied to the following equation (eqn (5)) from which $n_{i}$ and the Freundlich constant $\left(K_{\mathrm{F}}\right)$ can be inferred.

$$
\log \left(q_{\mathrm{e}}\right)=n_{i} \log \left(C_{\mathrm{e}}\right)+\log K_{\mathrm{F}}
$$

Using these values, the distribution coefficent for the Freundlich isotherm was calculated, eqn (6), in which $C_{\max }$ was the maximum uranium concentration used within the isotherm range studied.

$$
K_{\mathrm{D}}=K_{\mathrm{F}} \times C_{\max }^{n_{i}-1}
$$

The free energy change of adsorption, $\Delta G^{\circ}$, was then calculated (eqn (7)) where $R$ was the universal gas constant $\left(8.314 \mathrm{~J} \mathrm{~mol}^{-1} \mathrm{~K}^{-1}\right)$, $T$ was temperature $\left(-248.15\right.$ Kelvin) and $K_{\mathrm{D}}$ was the distribution coefficient.

$$
\Delta G^{\circ}=-R T \ln K_{\mathrm{D}}
$$

The corresponding Freundlich constants, $K_{\mathrm{F}}, K_{\mathrm{D}}$, and $\Delta G^{\circ}$ values (Table 3 ) confirm that the bacterial cell walls of both

\begin{tabular}{|c|c|c|c|c|}
\hline & $\mathrm{pH}$ & $K_{\mathrm{F}}, \mathrm{mol} \mathrm{kg}^{-1}$ & $K_{\mathrm{D}}, \mathrm{L} \mathrm{g}^{-1}$ & $\Delta G^{\circ}, \mathrm{kJ} \mathrm{mol}^{-1}$ \\
\hline \multicolumn{5}{|c|}{ Pseudomonas putida 33015} \\
\hline \multirow[t]{3}{*}{ Intact cells } & 3 & $9.59 \pm 0.45$ & $199.75 \pm 9.30$ & $-13.12 \pm 0.11$ \\
\hline & 4.25 & $20.89 \pm 0.98$ & $260.34 \pm 2.24$ & $-13.78 \pm 0.02$ \\
\hline & 5.5 & $273.02 \pm 31.09$ & $621.00 \pm 12.99$ & $-15.94 \pm 0.05$ \\
\hline \multirow[t]{3}{*}{ Cell wall } & 3 & $14.68 \pm 1.24$ & $234.08 \pm 6.17$ & $-13.52 \pm 0.07$ \\
\hline & 4.25 & $36.15 \pm 1.89$ & $322.50 \pm 7.71$ & $-14.32 \pm 0.06$ \\
\hline & 5.5 & $329.82 \pm 19.44$ & $685.12 \pm 7.77$ & $-16.19 \pm 0.03$ \\
\hline \multirow[t]{3}{*}{ Cell membrane } & 3 & $6.78 \pm 0.47$ & $174.52 \pm 4.63$ & $-12.80 \pm 0.07$ \\
\hline & 4.25 & $20.21 \pm 2.04$ & $255.82 \pm 5.97$ & $-13.74 \pm 0.06$ \\
\hline & 5.5 & $187.36 \pm 9.01$ & $565.42 \pm 7.86$ & $-15.71 \pm 0.03$ \\
\hline \multicolumn{5}{|c|}{ Bacillus subtilis 168} \\
\hline \multirow[t]{3}{*}{ Intact cells } & 3 & $13.00 \pm 0.50$ & $218.00 \pm 3.54$ & $-13.35 \pm 0.04$ \\
\hline & 4.25 & $47.54 \pm 0.72$ & $353.46 \pm 2.37$ & $-14.55 \pm 0.02$ \\
\hline & 5.5 & $326.44 \pm 7.40$ & $688.18 \pm 7.70$ & $-16.20 \pm 0.02$ \\
\hline \multirow[t]{3}{*}{ Cell wall } & 3 & $24.69 \pm 1.01$ & $239.95 \pm 12.57$ & $-13.58 \pm 0.13$ \\
\hline & 4.25 & $89.68 \pm 1.60$ & $366.83 \pm 2.70$ & $-14.64 \pm 0.02$ \\
\hline & 5.5 & $796.34 \pm 66.23$ & $796.62 \pm 12.10$ & $-16.56 \pm 0.04$ \\
\hline \multirow[t]{3}{*}{ Cell membrane } & 3 & $3.48 \pm 0.8$ & $129.20 \pm 4.64$ & $-12.05 \pm 0.09$ \\
\hline & 4.25 & $8.73 \pm 0.22$ & $189.21 \pm 2.19$ & $-13.00 \pm 0.03$ \\
\hline & 5.5 & $170.76 \pm 32.28$ & $539.93 \pm 32.80$ & $-15.59 \pm 0.15$ \\
\hline
\end{tabular}
species, are the governing component for uranium biosorption

Table 3 Constants obtained from Freundlich isotherms, at $298.15 \mathrm{~K}$ 
from contaminated waters at the cell envelope, in comparison to the cell membrane, whole intact cells and previous studies. ${ }^{56,57}$ An increase in $K_{\mathrm{D}}$ and negative values of $\Delta G^{\circ}$ as the $\mathrm{pH}$ increased suggests energetically favourable biosorption conditions towards circumneutral $\mathrm{pH}$ due to deprotonation of functional groups and an increase in the bioavailability of uranium-favourable biosorption sites. Comparison of theoretical and experimental $q_{\mathrm{e}}$ values is shown in Fig. S4 (ESI $\dagger$ ).

The Langmuir isotherm model was also used to examine the data, however, the quality of fits obtained was not adequate and hence it was deemed not appropriate to report here (but see Table S2 and Fig. S5, ESI $\dagger$ ).

\subsection{ATR-FT-IR}

ATR-FT-IR was used to identify the functional groups for each component of the cell envelope. Using this technique, any changes in adsorption band shape and position in a spectrum provides identification of the functional groups of chemical molecules involved in uranium biosorption. The main infrared bands and functional groups identified for intact cells, cell wall and membrane components of P. putida and B. subtilis are summarised in Table $4 .^{5,12-14,38-41,58-63}$ FT-IR spectra of the intact cells, cell wall and cell surface membrane of $P$. putida and $B$. subtilis, before and after $\mathrm{U}(\mathrm{vI})$ biosorption at $\mathrm{pH} 5.5$ are shown in Fig. 3. Detailed interpretation of control spectra is given in Supplementary Information 2 (ESI $\dagger$ ). Adsorption spectra were normalised with respect to the amide I absorption band, the adsorption band characteristic of functional groups associated with bacterial proteins, ${ }^{41}$ present in all isolates. Differences in adsorption band intensity, in comparison to intact cells, corresponded to changes in the relative abundance of biomolecules following the extraction, isolation and purification of the cell wall and cell membrane from both bacterial strains. Futhermore, this eliminated interference from IR radiation interacting with functional groups associated with intracellular components of intact cells. ${ }^{38,39,41}$ The spectra for the intact cell control, the cell wall and cell membrane (control) shows the signal characteristic of the components obtained through the
XPS characterisation: peptides, polysaccharides and hydrocarbons. The spectra shows that the extraction process caused little changes to the structure at macromolecular level, the shape and position of the peaks in the spectra corresponds to previously reported FT-IR for bacteria cell wall. ${ }^{41,42}$ The intensity of the band in the fingerprint region for the polysaccharides $\left(1080 \mathrm{~cm}^{-1}\right)$ in the cell wall control spectrum is slightly higher than the cell membrane, since it is expected that there is more polysaccharides in this fraction since polysaccharides are the mainly located at the cell wall. This corroborates the results obtained from the calculated distribution of components using XPS.

3.3.1 Uranium biosorption mechanisms. Changes in adsorption band position and intensity suggest different mechanisms of uranium binding to the different functional moieties of each component of the cell envelope. Uranium biosorption was confirmed by the $\nu\left(\mathrm{U}-\mathrm{O}_{\text {ligand }}\right)$ absorption band in ATR-FT-IR spectra. Changes in shape and intensity of the broad and strong adsorption band between $3700-3000 \mathrm{~cm}^{-1}$ from O-H stretching vibrations of hydroxyl groups and $\mathrm{N}-\mathrm{H}$ stretching of amino groups were associated with uranium binding in intact cells and isolated surface components. ${ }^{40,61,64}$ Changes in absorption band position of spectra for intact cells of both bacterial strains studied suggested that phosphorylated biopolymers, amide and carboxyl groups from proteins and polysaccharides associated with the cell envelope were responsible for uranium retention within the $\mathrm{pH}$ range studied. Changes in absorption band position corresponding to the $\nu_{\text {as }}\left(\mathrm{PO}_{2}\right)$ of phosphate and broadening of the $\nu_{\mathrm{s}}\left(\mathrm{COO}^{-}\right)$band from proteins were observed for intact $P$. putida and B. subtilis cells that retained uranium. These changes were more apparent at $\mathrm{pH}$ 5.5. Deprotonation of functional groups as the $\mathrm{pH}$ increased resulted in a greater retention of uranium and hence a greater change in absorption band position and shape. Differences in the absorption band position, corresponding to the $\nu(\mathrm{C}-\mathrm{O}, \mathrm{C}-\mathrm{O}-\mathrm{C}, \mathrm{C}-\mathrm{C})$ were observed in spectra when intact $P$. putida cells biosorbed uranium. No significant change in the absorption band position was observed for intact B. subtilis cells, suggesting that peptidoglycan within the cell envelope was not a significant contributing factor in uranium biosorption. These results support the

Table 4 Infrared absorption bands and their corresponding function group assignments in intact cells, cell wall and membrane fractions. $\nu$ denotes stretching vibrations, $\delta$ denotes bending vibrations. Subscript s labels symmetric stretching and subscript as labels asymmetric stretching

\begin{tabular}{ll}
$\begin{array}{l}\text { Wavenumber } \\
\left(\sigma\left(\mathrm{cm}^{-1}\right)\right)\end{array}$ & Functional group assignment ${ }^{\mathrm{a}}$ \\
\hline$\sim 3300$ & $\nu(\mathrm{O}-\mathrm{H})$ of hydroxyl groups \\
$\sim 3000-2850$ & $\nu_{\mathrm{as}}\left(\mathrm{CH}_{3}\right), \nu_{\mathrm{as}}\left(\mathrm{CH}_{2}\right)$ and $\nu_{\mathrm{s}}\left(\mathrm{CH}_{2}\right)$ from lipids \\
$\sim 1740-1720$ & $\nu_{\mathrm{s}}(\mathrm{C}=\mathrm{O})$ from esters in lipids, (lipo)teichoic acids, stretching of $\mathrm{C}=\mathrm{O}$ from carboxylic acids \\
$\sim 1650$ & $\nu(\mathrm{C}=\mathrm{O})$ from proteins (Amide $\mathrm{I})$ \\
$\sim 1540$ & $\delta(\mathrm{N}-\mathrm{H})$ from proteins (Amide II $)$ \\
$\sim 1470-1450$ & $\delta_{\mathrm{s}}\left(\mathrm{CH}_{2}\right)$ from lipids and fatty acids \\
$\sim 1420-1380$ & $\nu_{\mathrm{s}}\left(\mathrm{COO}^{-}\right)$from proteins \\
$\sim 1320$ & $\nu(\mathrm{C}-\mathrm{N})$ from proteins \\
$\sim 1240-1220$ & $\nu_{\mathrm{as}}\left(\mathrm{PO}_{2}\right)$ from DNA, phospholipids and phosphorylated biopolymers \\
$\sim 1175$ & $\nu_{\mathrm{s}}\left(\mathrm{PO}_{2}\right)$ from DNA, phospholipids and phosphorylated biopolymers \\
$\sim 1080-1040$ & $\nu_{\mathrm{s}}\left(\mathrm{PO}_{2}, \mathrm{PO}_{3}{ }^{2-}\right)$ from DNA, phospholipids and phosphorylated biopolymers; $\nu(\mathrm{C}-\mathrm{OH}, \mathrm{C}-\mathrm{O}-\mathrm{C}, \mathrm{C}-\mathrm{C})$ \\
& from polysaccharides, peptidoglycan \\
$\sim 976$ & $\nu_{\mathrm{s}}\left(\mathrm{PO}_{2}\right)$ from DNA, phospholipids and phosphorylated biopolymers \\
$\sim 915-925$ & $\nu\left(\mathrm{U}_{-}-\mathrm{O}_{\text {ligand }}\right)$ from uranium following biomass accumulation.
\end{tabular}



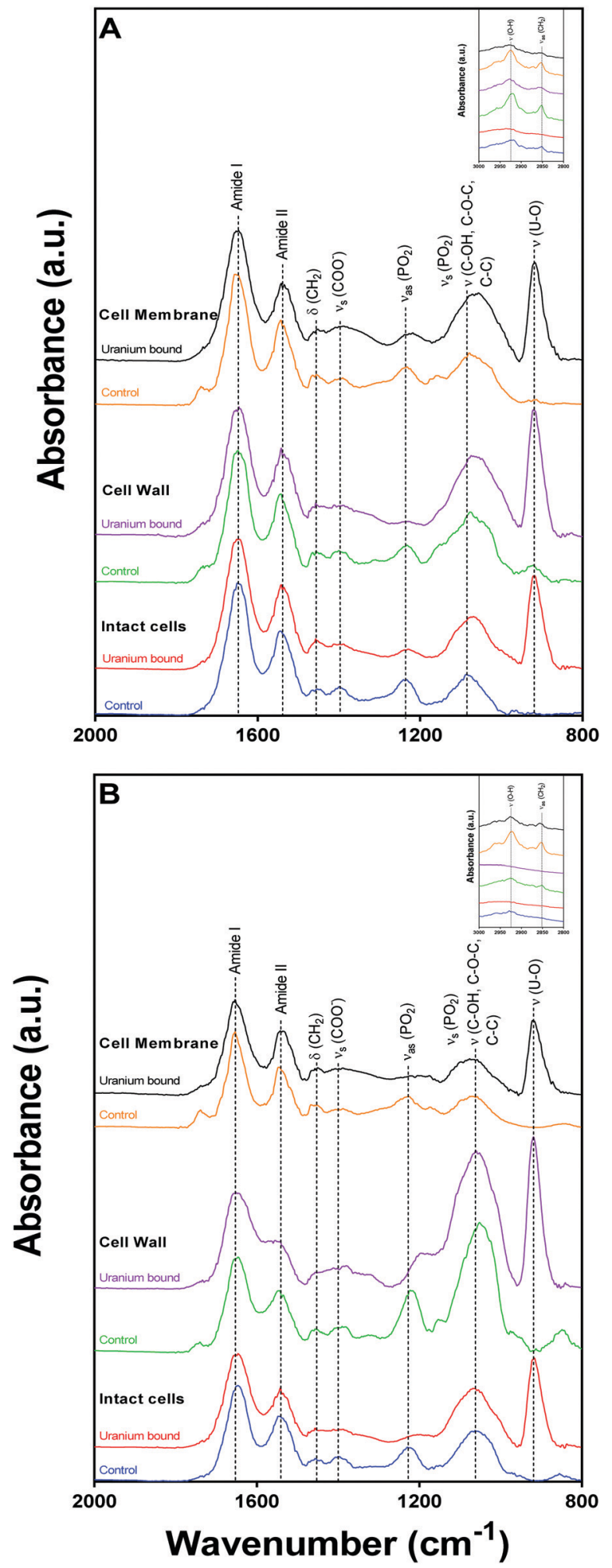

Fig. 3 FTIR spectra of control and uranium loaded biomass $(\mathrm{pH} 5.5)$ from $P$. putida $33015[\mathrm{~A}]$ and $B$. subtilis $168[\mathrm{~B}]$ within the region of $2000-800 \mathrm{~cm}^{-1}$. Insets in the region of $3000-2800 \mathrm{~cm}^{-1}$.

suggestion that phosphate and carboxyl groups from phosphorylated biomolecules and proteins at the surface of intact cells are important for uranium biosorption from solution, with preferential binding to different functional groups, depending on cell type. The results were comparable with other studies using FT-IR to investigate uranium interactions with intact cells that suggested that phosphate, carboxyl, hydroxyl and amino groups were the predominant functional groups responsible for uranium retention. ${ }^{61,64-67}$ Furthermore, other spectroscopic techniques, including EXAFS and TRFLS, used to investigate uranium interactions with intact bacterial cells, suggested a similar process of uranium sequestration i.e. predominantly through phosphate groups. ${ }^{17,20,22,24,26,67-69}$

The cell wall isolates from P. putida and B. subtilis exhibited different uranium biosorption mechanisms due to differences in cell wall architecture. Spectra suggested that biomolecules within the outer membrane of the Gram-negative cell wall of P. putida were responsible for uranium biosorption. A decrease in intensity of the $\nu_{\text {as }}\left(\mathrm{CH}_{3}\right), \nu_{\text {as }}\left(\mathrm{CH}_{2}\right)$ and $\nu_{\mathrm{s}}\left(\mathrm{CH}_{2}\right)$ absorption bands $\left(\sim 3000-2850 \mathrm{~cm}^{-1}\right)$, associated with lipid material, was seen following uranium binding. Broadening and changes in shape of protein adsorption bands (amide II and $\nu_{\mathrm{s}}\left(\mathrm{COO}^{-}\right)$) suggested uranium-favourable interactions with proteins in the cell wall. As for intact cells, broadening in absorption bands, the corresponding $\nu_{\text {as }}\left(\mathrm{PO}_{2}\right)$ of phosphorylated polymers and $\nu(\mathrm{C}-\mathrm{O}, \mathrm{C}-\mathrm{O}-\mathrm{C}, \mathrm{C}-\mathrm{C})$ of polysaccharides, suggested that phospholipids from the outer membrane and lipopolysaccharides (LPS) were involved in uranium biosorption by the Gramnegative bacterial cell wall. ${ }^{14,15,39,40,63}$ This was supported by previous studies suggesting that LPS sequestered uranium from solution using phosphate and carboxyl groups. ${ }^{30,32}$

There was no significant shift in absorption bands corresponding to the $\nu(\mathrm{C}-\mathrm{O}, \mathrm{C}-\mathrm{O}-\mathrm{C}, \mathrm{C}-\mathrm{C})$ of polysaccharides following uranium biosorption to cell wall components, except at high concentrations of uranium at $\mathrm{pH} 5.5$, similar to the results observed for intact B. subtilis cells. This suggested that the biosorption of uranium with peptidoglycan within the Grampositive cell wall was a $\mathrm{pH}$ dependent process and occurred to a greater extent when it was exposed to high uranium concentrations. The $\mathrm{p} K_{\mathrm{a}}$ values of purified peptidoglycan have been reported to be 4.55, 6.31 and 9.56, corresponding to the carboxyl groups of glutamic acid, diaminopimelic acid and a combination of hydroxyl/amino groups, respectively. ${ }^{31}$ Considering the experimental conditions used in this study, a deprotonation of the majority of functional groups associated with polysaccharides within the cell wall isolate at pH 5.5 was expected, enabling the biosorption of uranium by cell wall components. Shifts corresponding to changes in the $\nu_{\text {as }}\left(\mathrm{PO}_{2}\right)$ absorption band position indicated uranium biosorption with phosphate groups within the Gram-positive cell wall, such as those in (lipo)teichoic acids and proteins associated with the phosphorylated cell wall. ${ }^{41}$ The latter was further confirmed by changes in the shape of protein associated absorption bands following uranium exposure within the $\mathrm{pH}$ range studied. Broadening of the $\delta(\mathrm{N}-\mathrm{H})$ and the $\nu_{\mathrm{s}}\left(\mathrm{COO}^{-}\right)$ absorption bands indicate interactions with carboxyl groups associated with cell wall proteins. ${ }^{64,70}$ Conformational changes in protein structure following uranium binding would probably contribute to changes in $\delta(\mathrm{N}-\mathrm{H})$ adsorption band shape rather than being due to uranium binding with amino groups. This is due to the $\mathrm{p} K_{\mathrm{a}}$ of amino groups being 9.0. Therefore, within the 
$\mathrm{pH}$ range studied, no binding interactions were expected since the positively charged amino groups prevent electrostatic binding with the positively charged $\mathrm{U}(\mathrm{vI})$ species. The small $\nu_{\mathrm{s}}(\mathrm{C}=\mathrm{O})$ band at $1734 \mathrm{~cm}^{-1}$ from (lipo)teichoic acids disappeared upon uranium biosorption suggested favourable interactions, with these cell wall constituents also anchored to the cell surface membrane. ${ }^{41}$

The results from uranium biosorption to cell membrane isolates from $P$. putida and B. subtilis were comparable, probably due to similarities in macromolecular composition. A decrease in the intensity of the absorption bands for $\nu_{\mathrm{as}}\left(\mathrm{CH}_{3}\right)$, $\nu_{\text {as }}\left(\mathrm{CH}_{2}\right)$ and $\nu_{\mathrm{s}}\left(\mathrm{CH}_{2}\right)$ was observed following uranium biosorption. This was attributed to overall changes in membrane structure following uranium biosorption, rather than direct binding to unreactive non-polar lipid material. ${ }^{23,24,26}$ Similarly, the additional adsorption band at $1740 \mathrm{~cm}^{-1}$, attributed to the vibrational stretching of the $\mathrm{C}=\mathrm{O}$ lipid bond and characteristic of cell membrane components following isolation from intact cells, disappeared following uranium biosorption. Shifts and broadening of $\nu_{\text {as }}\left(\mathrm{PO}_{2}\right)$ and $\nu_{\mathrm{s}}\left(\mathrm{PO}_{2}\right)$ absorption bands from isolates of both bacterial strains suggested favourable U(vI)-phosphate interactions with phospholipids of the cell surface membrane. Finally, the broadening of the protein absorption bands associated with carboxyl groups in both membrane isolates indicated that there were interactions with membrane associated proteins.

Overall, the ATR-FT-IR data suggested that numerous functional groups are responsible for uranium biosorption at the cell surface and that this process is predominantly dependent on those groups associated with the cell wall. The level of biosorption varies due to solution $\mathrm{pH}$ and is influenced by the composition of bacterial cell envelope; whether it be of Gram-negative or Gram-positive origin. The major functional groups associated with uranium biosorption were phosphate and carboxyl, from phosphorylated proteins, phospholipids and polysaccharides. Differences in uranium biosorption mechanisms were observed between the intact cells and cell wall isolates of $P$. putida and B. subtilis. Cell membrane components exhibited a similar mechanism of uranium biosorption due to similarities in macromolecular composition, regardless of bacterial origin.

Based on these results, Fig. 4 shows the different interactions of the cell envelope of both Gram-negative and Gram-positive bacteria. $\mathrm{U}(\mathrm{vI})$ species will interact with negatively charged components of the outer membrane of the cell wall of Gram-negative bacteria, including lipopolysaccharides and capsular polysaccharides, membrane and surface proteins, and components of outer membrane phospholipids. Further interactions will occur with the small amounts of peptidoglycan below the outer membrane. In the case of Gram-positive bacteria, $\mathrm{U}(\mathrm{vI})$ species will readily bind to phosphorylated polysaccharides, including teichoic acids, and cell surface and wall associated proteins. U(v) will also interact favourably with peptidogyclan towards circumneutral $\mathrm{pH}$.

In the case of the cell membrane, both Gram-negative and Gram-positive bacteria display similar mechanisms of interaction with $\mathrm{U}(\mathrm{vI})$, mainly through phospholipids and membrane associated proteins. Additionally, U(vI) will interact with cell membrane bound lipoteichoic acids associated solely with Gram-positive bacteria. The sorption process is favoured by the ability of $\mathrm{U}(\mathrm{vI})$ to travel through the outer membrane layer of the Gram-negative cell wall and peptidoglycan layers of both cell envelopes The size of the uranyl ion is significantly smaller (approximately $0.242 \mathrm{~nm}^{71}$ ) compared to the pore size of peptidoglycan for $B$. subtilis $\left(2.12-2.5 \mathrm{~nm}^{72-74}\right)$, for example, suggesting that diffusion of uranyl that is not bound by the outer membrane layer can occur, facilitating the sorption process with cell membrane compounds.

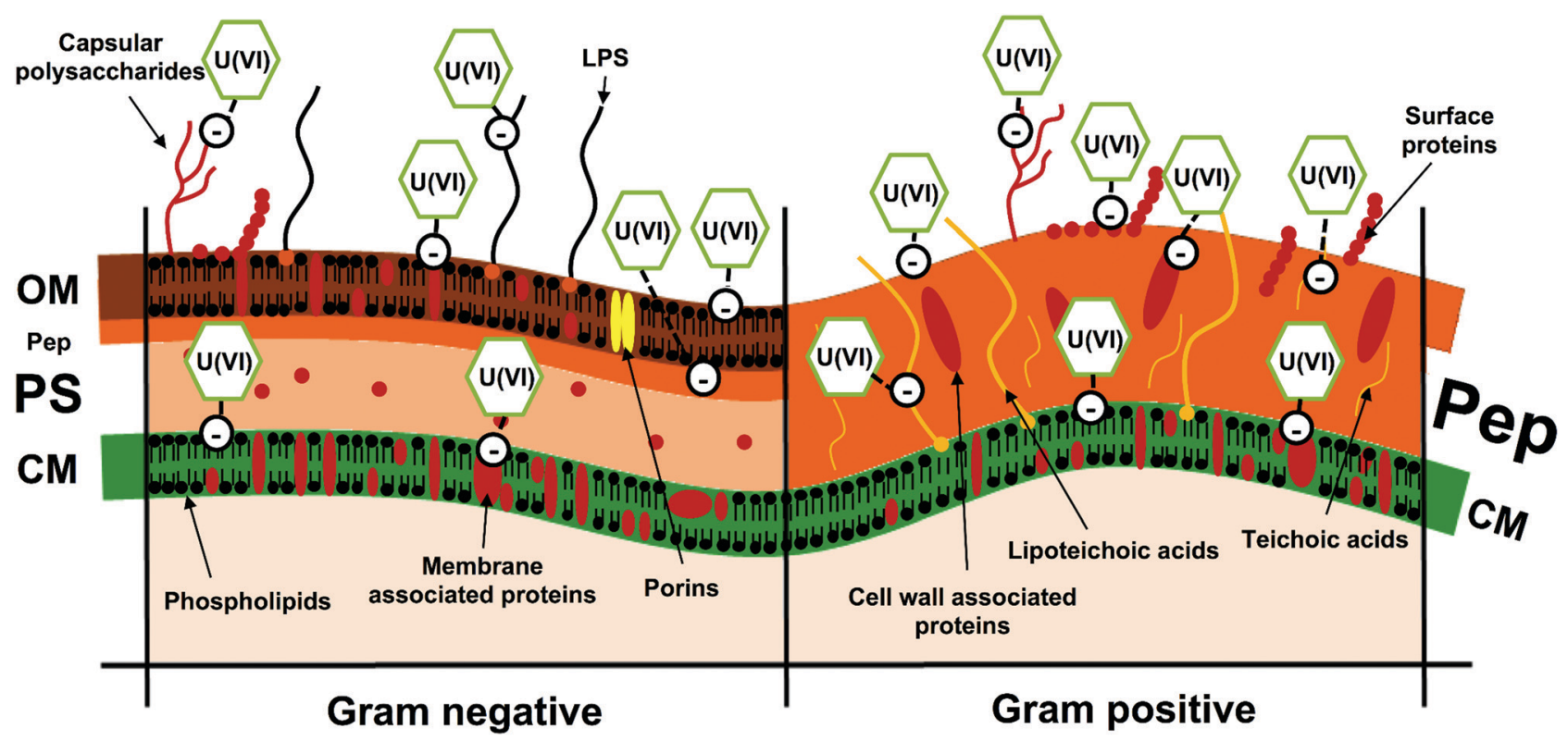

Fig. 4 The proposed interactions of uranium(vI) with the cell wall and cell surface membrane from Gram negative and Gram positive bacteria in aerobic conditions. OM: outer membrane, Pep: peptidoglycan layer, PS: periplasmic space, CM: cell surface membrane, LPS: lipopolysaccharides. 


\section{Conclusions}

The current study demonstrated that the bacterial cell wall is the vital component in the biosorption of $\mathrm{U}(\mathrm{vI})$. The capacity of cell wall components to retain uranium(vi) is larger than any other component of the cell envelope. The findings from this study indicate that Gram-positive bacteria and associated components of their cell envelope exhibited a greater biosorption capacity than components of the Gram-negative cell envelope. The preference for uranium biosorption with isolated cell envelope components and intact cells can be summarised as;

$$
\text { Cell wall }>\text { Intact cells }>\text { Cell membrane }
$$

It was also found that carboxyl and phosphate functional moieties from proteins and phosphorylated biopolymers, associated with the cell wall, predominantly mediate $\mathrm{U}(\mathrm{v})$ biosorption from aqueous solutions. This confirms that the biosorption mechanism is predominantly a surface process with the outermost components of the bacterial cell envelope. Furthermore, this study showed the cell membrane exhibits a lower capacity for $\mathrm{U}(\mathrm{vI})$ biosorption. Therefore uranium(vi) in solution will not be retained by cell membrane functional groups and accumulate at the cell wall since the chemical environment is more favourable for its retention. The question remains whether this is a diffusion or kinetically driven process, but this issue was beyond the scope of this study.

Overall, the findings from this study further aid with the design and use of bacteria for the remediation of uranium contaminated environments. A remediation process that uses Gram-positive bacteria would have a higher chance of success based on the superior ability of the components of their cell envelope to remove $\mathrm{U}(\mathrm{vI})$ from solution.

\section{Conflicts of interest}

There are no conflicts to declare.

\section{Acknowledgements}

The authors thank the EPSRC consortium "Hard-soft matter interfaces: from understanding to engineering” (EP/I001514/1) for financial support during the experimental study. Further thanks go to Dr Deborah Hammond and Dr Mathew Pringle (The University of Sheffield) for help with XPS data acquisition and interpretation.

\section{References}

1 T. Arnold, N. Baumann, E. Krawczyk-Baersch, S. Brockmann, U. Zimmermann, U. Jenk and S. Weiss, Geochim. Cosmochim. Acta, 2011, 75, 2200-2212.

2 J. R. Lloyd and J. C. Renshaw, in Metal Ions in Biological Systems, Vol 44, ed. A. Sigel, H. Sigel and R. K. O. Sigel, 2005, vol. 44, pp. 205-240.

3 G. M. Gadd, New Phytol., 1993, 124, 25-60.

4 N. Das, Hydrometallurgy, 2010, 103, 180-189.
5 J. Wang and C. Chen, Biotechnol. Adv., 2009, 27, 195-226.

6 L. E. Macaskie, R. M. Empson, A. K. Cheetham, C. P. Grey and A. J. Skarnulis, Science, 1992, 257, 782-784.

7 L. E. Macaskie, K. M. Bonthrone, P. Yong and D. T. Goddard, Microbiology, 2000, 146, 1855-1867.

8 S. Choudhary and P. Sar, Rev. Environ. Sci. Biotechnol., 2015, 14, 347-355.

9 L. Newsome, K. Morris and J. R. Lloyd, Chem. Geol., 2014, 363, 164-184.

10 M. Gavrilescu, L. V. Pavel and I. Cretescu, J. Hazard. Mater., 2009, 163, 475-510.

11 S. A. Cumberland, G. Douglas, K. Grice and J. W. Moreau, Earth-Sci. Rev., 2016, 159, 160-185.

12 J. J. Ojeda, M. E. Romero-Gonzalez, R. T. Bachmann, R. G. J. Edyvean and S. A. Banwart, Langmuir, 2008, 24, 4032-4040.

13 J. J. Ojeda, M. E. Romero-Gonzalez, H. M. Pouran and S. A. Banwart, Mineral. Mag., 2008, 72, 101-106.

14 J. J. Ojeda, M. E. Romero-Gonzalez and S. A. Banwart, Anal. Chem., 2009, 81, 6467-6473.

15 M. L. Merroun, G. Geipel, R. Nicolai, K. H. Heise and S. Selenska-Pobell, Biometals, 2003, 16, 331-339.

16 D. A. Fowle, J. B. Fein and A. M. Martin, Environ. Sci. Technol., 2000, 34, 3737-3741.

17 S. D. Kelly, K. M. Kemner, J. B. Fein, D. A. Fowle, M. I. Boyanov, B. A. Bunker and N. Yee, Geochim. Cosmochim. Acta, 2002, 66, 3855-3871.

18 D. Gorman-Lewis, P. E. Elias and J. B. Fein, Environ. Sci. Technol., 2005, 39, 4906-4912.

19 P. J. Panak, R. Knopp, C. H. Booth and H. Nitsche, Radiochim. Acta, 2002, 90, 779-783.

20 M. L. Merroun, J. Raff, A. Rossberg, C. Hennig, T. Reich and S. Selenska-Pobell, Appl. Environ. Microbiol., 2005, 71, 5532-5543.

21 J. Zhang, H. Song, Z. Chen, S. Liu, Y. Wei, J. Huang, C. Guo, Z. Dang and Z. Lin, Chemosphere, 2018, 206, 682-692.

22 T. Reitz, A. Rossberg, A. Barkleit, S. Selenska-Pobell and M. L. Merroun, PLoS One, 2014, 9, e102447.

23 L. Luetke, H. Moll and G. Bernhard, Dalton Trans., 2012, 41, 13370-13378.

24 I. Llorens, G. Untereiner, D. Jaillard, B. Gouget, V. Chapon and M. Carriere, PLoS One, 2012, 7, e51783.

25 X.-Y. Zheng, X.-Y. Wang, Y.-H. Shen, X. Lu and T.-S. Wang, Chemosphere, 2017, 175, 161-169.

26 M. L. Merroun, M. Nedelkova, J. J. Ojeda, T. Reitz, M. Lopez Fernandez, J. M. Arias, M. Romero-Gonzalez and S. SelenskaPobell, J. Hazard. Mater., 2011, 197, 1-10.

27 U. Gerber, I. Zirnstein, E. Krawczyk-Baersch, H. Luensdorf, T. Arnold and M. L. Merroun, J. Hazard. Mater., 2016, 317, 127-134.

28 M. Lopez-Fernandez, O. Fernandez-Sanfrancisco, A. MorenoGarcia, I. Martin-Sanchez, I. Sanchez-Castro and M. Larbi Merroun, Appl. Geochem., 2014, 49, 77-86.

29 M. L. Merroun and S. Selenska-Pobell, J. Contam. Hydrol., 2008, 102, 285-295.

30 A. Barkleit, H. Moll and G. Bernhard, Dalton Trans., 2008, 2879-2886. 
31 A. Barkleit, H. Moll and G. Bernhard, Dalton Trans., 2009, 5379-5385, DOI: 10.1039/b818702a.

32 A. Barkleit, H. Foerstendorf, B. Li, A. Rossberg, H. Moll and G. Bernhard, Dalton Trans., 2011, 40, 9868-9876.

33 S. Xiang, X. Nie, F. Dong, W. Cheng, M. Liu, C. Ding, L. Bian, S. Sun and H. Li, J. Mol. Liq., 2020, 305, 112852.

34 P. G. Rouxhet, N. Mozes, P. B. Dengis, Y. F. Dufrene, P. A. Gerin and M. J. Genet, Colloids Surf., B, 1994, 2, 347-369.

35 Y. F. Dufrene and P. G. Rouxhet, Colloids Surf., B, 1996, 7, 271-279.

36 Y. F. Dufrene, A. VanderWal, W. Norde and P. G. Rouxhet, J. Bacteriol., 1997, 179, 1023-1028.

37 H. C. van der Mei, J. de Vries and H. J. Busscher, Surf. Sci. Rep., 2000, 39, 3-24.

38 A. A. Kamnev, L. P. Antonyuk, L. Y. Matora, O. B. Serebrennikova, M. V. Sumaroka, M. Colina, M. F. RenouGonnord and V. V. Ignatov, J. Mol. Struct., 1999, 481, 387-393.

39 L. Shakirova, M. Grube, R. Goodacre, M. Gavare, L. Auzina and P. Zikmanis, Vib. Spectrosc., 2013, 64, 51-57.

40 M. J. Baker, J. Trevisan, P. Bassan, R. Bhargava, H. J. Butler, K. M. Dorling, P. R. Fielden, S. W. Fogarty, N. J. Fullwood, K. A. Heys, C. Hughes, P. Lasch, P. L. Martin-Hirsch, B. Obinaju, G. D. Sockalingum, J. Sule-Suso, R. J. Strong, M. J. Walsh, B. R. Wood, P. Gardner and F. L. Martin, Nat. Protoc., 2014, 9, 1771-1791.

41 W. Jiang, A. Saxena, B. Song, B. B. Ward, T. J. Beveridge and S. C. B. Myneni, Langmuir, 2004, 20, 11433-11442.

42 J. J. Ojeda and M. Dittrich, Methods Mol. Biol., 2012, 881, 187-211.

43 T. J. Smith and S. J. Foster, J. Bacteriol., 1995, 177, 3855-3862.

44 A. S. Eswayah, T. J. Smith, A. C. Scheinost, N. Hondow and P. H. Gardiner, Appl. Microbiol. Biotechnol., 2017, 101, 6713-6724.

45 T. J. Smith and S. J. Foster, FEMS Microbiol. Lett., 1997, 157, 141-147.

46 T. J. Smith, S. A. Blackman and S. J. Foster, Microbiology, 2000, 146, 249-262.

47 A. Kuroda and J. Sekiguchi, Microbiology, 1990, 136, 2209-2216.

48 J. E. Fein and H. J. Rogers, J. Bacteriol., 1976, 127, 1427-1442.

49 F. A. Nugroho, H. Yamamoto, Y. Kobayashi and J. Sekiguchi, J. Bacteriol., 1999, 181, 6230-6237.

50 F. Ahimou, C. J. P. Boonaert, Y. Adriaensen, P. Jacques, P. Thonart, M. Paquot and P. G. Rouxhet, J. Colloid Interface Sci., 2007, 309, 49-55.

51 M. Ramstedt, L. Leone, P. Persson and A. Shchukarev, Langmuir, 2014, 30, 4367-4374.
52 H. Moriwaki, R. Koide, R. Yoshikawa, Y. Warabino and H. Yamamoto, Appl. Microbiol. Biotechnol., 2013, 97, 3721-3728. 53 V. P. Harden and J. O. Harris, J. Bacteriol., 1953, 65, 198-202. 54 J. B. Fein, C. J. Daughney, N. Yee and T. A. Davis, Geochim. Cosmochim. Acta, 1997, 61, 3319-3328.

55 A. Borkowski, M. Szala and T. Clapa, Appl. Biochem. Biotechnol., 2015, 175, 1448-1459.

56 S. Xie, J. Yang, C. Chen, X. Zhang, Q. Wang and C. Zhang, J. Environ. Radioact., 2008, 99, 126-133.

57 M. Amini, H. Younesi and N. Bahramifar, J. Environ. Eng., 2013, 139, 410-421.

58 S. J. Parikh and J. Chorover, Langmuir, 2006, 22, 8492-8500.

59 D. S. Alessi, J. S. Lezama-Pacheco, J. E. Stubbs, M. Janousch, J. R. Bargar, P. Persson and R. Bernier-Latmani, Geochim. Cosmochim. Acta, 2014, 131, 115-127.

60 G. J. Lumetta, B. K. McNamara, B. M. Rapko and J. E. Hutchison, Inorg. Chim. Acta, 1999, 293, 195-205.

61 S. K. Kazy, S. F. D’Souza and P. Sar, J. Hazard. Mater., 2009, 163, 65-72.

62 S. Yagoubi, C. Renard, F. Abraham and S. Obbade, J. Solid State Chem., 2013, 200, 13-21.

63 S. K. Kazy, P. Sar and S. F. D’Souza, Biorem. J., 2008, 12, 47-57. 64 S. Choudhary and P. Sar, J. Hazard. Mater., 2011, 186, 336-343. 65 X. H. Pan, Z. Chen, F. B. Chen, Y. J. Cheng, Z. Lin and X. Guan, J. Hazard. Mater., 2015, 297, 313-319.

66 X. Lu, X.-J. Zhou and T.-S. Wang, J. Hazard. Mater., 2013, 262, 297-303.

67 N. Theodorakopoulos, V. Chapon, F. Coppin, M. Floriani, T. Vercouter, C. Sergeant, V. Camilleri, C. Berthomieu and L. Fevrier, J. Hazard. Mater., 2015, 285, 285-293.

68 N. Renninger, R. Knopp, H. Nitsche, D. S. Clark and J. D. Keasling, Appl. Environ. Microbiol., 2004, 70, 7404-7412.

69 F. Morcillo, M. T. Gonzalez-Munoz, T. Reitz, M. E. RomeroGonzalez, J. M. Arias and M. L. Merroun, PLoS One, 2014, 9, e91305.

70 F. Pagnanelli, M. P. Papini, L. Toro, M. Trifoni and F. Veglio, Environ. Sci. Technol., 2000, 34, 2773-2778.

71 Y. Oda and A. Aoshima, J. Nucl. Sci. Technol., 2002, 39, 647-654.

72 W. Vollmer, D. Blanot and M. A. De Pedro, FEMS Microbiol. Rev., 2008, 32, 149-167.

73 P. Demchick and A. L. Koch, J. Bacteriol., 1996, 178, 768-773.

74 R. Hughes, P. Thurman and E. Stokes, Z. Immunitaetsforsch., Exp. Klin. Immunol., 1975, 149, 126. 